\title{
TINJAUAN HUKUM LAUT TERHADAP WILAYAH NEGARA KESATUAN REPUBLIK INDONESIA
}

\author{
Tommy Hendra Purwaka*
}

Bagian Hukum Internasional, Fakultas Hukum Universitas Katolik Indonesia Atma Jaya, Jakarta Jalan Jenderal Sudirman No. 51 Setiabudi, Jakarta Selatan, DKI Jakarta 12930

\begin{abstract}
Based on UNCLOS 1958 and 1960, national territory of Indonesia since 1945 up to 1994 had not yet entirely united. The application of 3 n.m. territorial sea encircling each island had placed waters among islands as high seas. After UNCLOS 1982 being implemented and internationally binding in 1994, the high seas became archipelagic waters and since that time have integrated the whole national territory of Indonesia.
\end{abstract}

Keywords: UNCLOS, national territory, Indonesia.

\section{Intisari}

Berdasarkan Konvensi Hukum Laut PBB (KHL) 1958 dan 1960, wilayah NKRI sejak 1945 sampai 1994 belum menyatu secara utuh. Penerapan laut teritorial 3 mil laut mengelilingi setiap pulau mengakibatkan wilayah laut di antara pulau-pulau merupakan laut lepas. Setelah KHL 1982 diberlakukan dan mengikat secara internasional pada tahun 1994, maka laut lepas berubah status menjadi perairan kepulauan yang menyatukan seluruh wilayah NKRI.

Kata Kunci: KHL, wilayah negara, NKRI.

\section{Pokok Muatan}

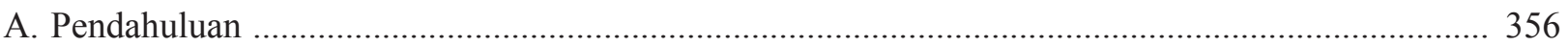

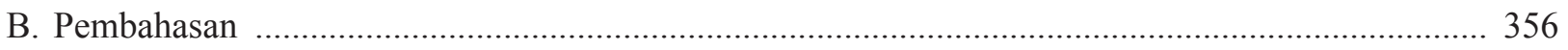

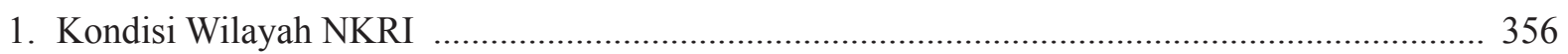

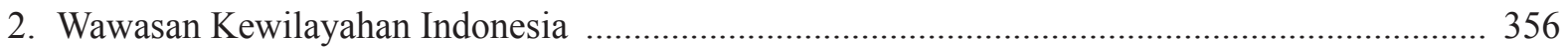

3. Kronologi Singkat Perkembangan Wilayah Laut Indonesia ..................................................... 357

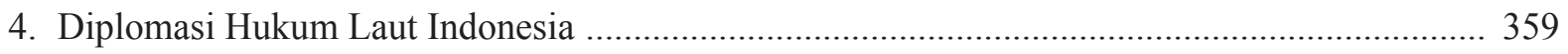

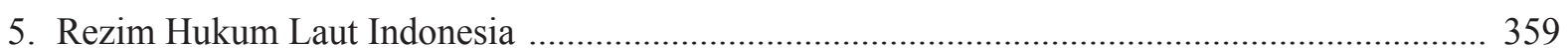

6. Perbatasan Wilayah Laut Indonesia ..................................................................................... 360

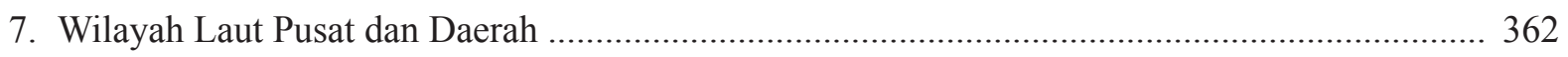

8. Kebijakan Kelautan Nasional tentang Wilayah Laut Indonesia ............................................... 363

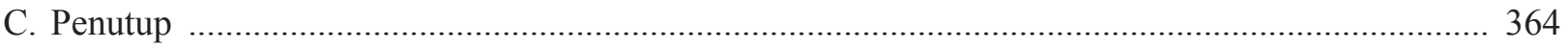

Alamat korespondensi: tommy.hendra@atmajaya.ac.id 


\section{A. Pendahuluan}

Indonesia mendeklarasikan wilayah laut nasionalnya sebagai satu kesatuan yang tak terpisahkan dari wilayah darat yang berbentuk pulau-pulau melalui Deklarasi Djuanda pada bulan Desember tahun 1957. Wilayah laut tersebut terdiri dari laut teritorial selebar 12 mil laut yang diukur dari garis pangkal kepulauan mengelilingi kepulauan Indonesia, perairan nusantara yang terletak di antara pulau-pulau, beserta dasar laut yang berada di bawahnya. Deklarasi Djuanda tersebut tetap mengakui hak-hak internasional seperti hak lintas damai kapal-kapal asing yang berlayar melalui perairan Indonesia serta pipa-pipa dan kabelkabel yang telah ada di dasar laut. Materi deklarasi tersebut kemudian dijadikan materi UU Nomor 4 Prp Tahun 1960 tentang Perairan Indonesia.

Wilayah laut NKRI yang sudah dideklarasikan tersebut belum berhasil diperjuangkan melalui KHL 1958 dan 1960 karena kedua konvensi menetapkan bahwa lebar laut teritorial setiap negara adalah 3 mil laut diukur dari garis pangkal. Bila Indonesia menerapkan laut teritorial selebar 3 mil laut mengelilingi setiap pulaunya, maka perairan laut yang berada di luar laut teritorial dan terletak di antara pulau-pulau mempunyai status hukum sebagai laut lepas (high seas) dimana berlaku kebebasan laut lepas (freedom of the high seas). Diplomasi untuk memperjuangkan wilayah perairan kepulauan Indonesia dilanjutkan baik melalui forum di luar PBB maupun di dalam PBB seperti Konferensi PBB III tentang Hukum Laut yang menghasilkan KHL 1982. KHL 1982 mengakui keberadaan negara kepulauan dengan lebar laut teritorial 12 mil laut mengelilingi wilayah kepulauan dari negara tersebut dan laut lepas yang berada di antara pulau berubah status hukumnya menjadi perairan kepulauan. Dengan demikian, KHL 1982 telah memungkinkan suatu negara kepulauan memiliki satu kesatuan wilayah negara.

\section{B. Pembahasan}

\section{Kondisi Wilayah NKRI}

Keberadaan suatu wilayah dengan batasbatas tertentu yang jelas merupakan salah satu syarat berdirinya suatu negara. Wilayah NKRI terdiri dari wilayah laut yang berada di bawah kedaulatan negara seluas 3,1 juta $\mathrm{km}^{2}$, wilayah laut dimana negara memiliki hak-hak berdaulat seluas 2,7 juta $\mathrm{km}^{2}$, wilayah darat seluas 1,9 juta $\mathrm{km}^{2}$ terdiri dari 17.508 pulau besar dan kecil dengan panjang pantai $81.900 \mathrm{~km}$, serta wilayah udara yang terdapat di atasnya. Jumlah penduduk yang bermukim secara tersebar tidak merata di pulau-pulau diperkirakan lebih dari 251 juta jiwa pada tahun 2013. Wilayah NKRI berbatasan dengan 10 (sepuluh) negara, yaitu India, Malaysia, Singapura, Thailand, Vietnam, Pilipina, Palau, Papua New Guinea, Australia, dan Timor Leste. ${ }^{1}$

Pemerintah berdasarkan UUD 1945 dan peraturan perundang-undangan yang terkait menguasai, mengelola dan menggunakan wilayah darat, laut dan udara serta kekayaan alam yang terkandung di dalamnya untuk sebesar-besar kemakmuran rakyat yang berjumlah 251 juta jiwa tersebut. Kondisi wilayah dengan batas-batas antar negara yang jelas, keberadaan rakyat dalam jumlah besar yang bermukim dan beraktivitas di wilayah tersebut, kehadiran pemerintahan negara yang berdaulat, serta pengakuan negara-negara lain dan masyarakat internasional khususnya melalui pemberlakuan KHL 1982 yang mengikat secara internasional telah memperkokoh eksistensi NKRI sebagai negara kepulauan terbesar di dunia.

\section{Wawasan Kewilayahan Indonesia}

Sejarah Indonesia mencatat bahwa di masa kejayaan Majapahit, Maha Patih Gajah Mada menyatakan Sumpah Palapa untuk mempersatukan berbagai wilayah di bawah kekuasaan Majapahit yang akan diberi nama Nuswantara atau Nusantara. Wilayah Nusantara adalah wilayah kepulauan 
Indonesia saat ini. Cara pandang kewilayahan dari Gajah Mada telah mengilhami Mochtar Kusumaatmadja untuk mengembangkan Wawasan Nusantara.

Wawasan Nusantara adalah suatu cara pandang kewilayahan terhadap wilayah NKRI sebagai kepulauan, yaitu satu kesatuan wilayah darat (pulau-pulau), laut dan udara di atasnya. Cara pandang kesatuan wilayah nusantara dikembangkan untuk membangkitkan kesadaran (consciousness) rakyat agar senantiasa mengupayakan dan mempertahankan satu kesatuan wilayah NKRI. Kenyataan menunjukkan bahwa sejak NKRI diproklamasikan pada tahun 1945 sampai dengan KHL 1982 diberlakukan dan mengikat secara internasional setelah negara ke 60 (enam puluh) meratifikasi KHL 1982 pada tahun 1994, wilayah laut yang terletak di antara pulau-pulau Indonesia menurut hukum laut internasional masih berstatus sebagai laut lepas. Wilayah laut lepas tersebut telah memisahkan pulau yang satu dari pulau-pulau lainnya dan sebagai konsekuensinya wilayah NKRI belum merupakan satu kesatuan wilayah yang utuh.

Wawasan Nusantara lahir pada saat pendeklarasian Deklarasi Djuanda pada bulan Desember 1957. Dalam kaitan ini, pendeklarasian tersebut dapat dipandang sebagai awal dari implementasi Wawasan Nusantara. Implementasi Wawasan Nusantara untuk selanjutnya dilakukan melalui perjuangan diplomasi hukum laut, pembangunan kelautan, dan pengembangan kebijakan kelautan nasional. Implementasi Wawasan Nusantara tersebut membawa perubahan cara pandang dari Wawasan Nusantara sebagai wawasan kewilayahan menjadi wawasan pembangunan, wawasan benua maritim, dan wawasan kebijakan kelautan nasional. ${ }^{2}$

\section{Kronologi Singkat Perkembangan Wila- yah Laut Indonesia}

Kronologi perkembangan wilayah laut NKRI dimulai: Pertama, pada saat para pemuda mengikrarkan Sumpah Pemuda pada tahun 1928 yang menyatakan Satu Nusa, Satu Bangsa, Satu Bahasa, dan Satu Tanah Air Indonesia. Dalam kaitannya dengan wilayah NKRI, Sumpah Pemuda tersebut menyatakan tekad para pemuda untuk memperjuangkan dan mempertahankan satu kesatuan wilayah darat, laut dan udara dari Sabang sampai Merauke dan dari Miangas sampai Pulau Rote sebagai satu kesatuan tanah air Indonesia.

Kedua, NKRI memproklamasikan kemerdekaannya pada tanggal 17 Agustus tahun 1945. Wilayah NKRI meliputi seluruh wilayah yang dulunya diduduki oleh pemerintah kolonial Belanda. Penafsiran analogis terhadap isi Naskah Proklamasi memberi pemahaman bahwa pemindahan kekuasaan atas wilayah pendudukan Belanda dilakukan dalam waktu yang sesingkat-singkatnya. Namun demikian, pemerintahan NKRI pada masa-masa awal kemerdekaannya belum memiliki kemampuan yang memadai untuk mengamankan wilayah lautnya. Sebagai akibatnya, wilayah laut sering digunakan oleh pihak asing untuk melakukan kegiatan pemecahbelahan NKRI. Siaran radio provokasi anti NKRI sering dipancarkan dari perairan kepulauan Indonesia. Kondisi sosial-politik dan pertahanankeamanan negara menjadi rentan. Langkah-langkah strategis untuk mengatasi permasalahan tersebut perlu segera diupayakan oleh pemerintah NKRI.

Ketiga, untuk mengatasi permasalahan tersebut di atas, pemerintah NKRI pada tahun 1957 mendeklarasikan Deklarasi Djuanda yang menyatakan bahwa wilayah laut yang terletak di antara pulau-pulau dan laut teritorial selebar 12 mil laut diukur dari garis pangkal lurus yang menghubungkan titik-titik terluar dari pulaupulau terluar mengelilingi kepulauan Indonesia ${ }^{3}$ merupakan bagian yang tak terpisahkan dari wilayah NKRI. Penarikan garis pangkal kepulauan yang terdiri dari garis-garis pangkal lurus mengelilingi kepulauan Indonesia diilhami oleh putusan International Court of Justice pada tahun 1951

Tommy Hendra Purwaka, "Paradigm Shift in the Implementation of the Law of the Sea in Indonesia", Indonesian Journal of International Law, Vol. 8, No. 1, Oktober 2010, hlm. 113-127.

R.R. Churcill dan A.V. Lowe, 1999, The Law of the Sea, Manchester University Press, Manchester, hlm. 50, $123,124$. 
dalam penyelesaian kasus perikanan antara Inggris dan Norwegia (Anglo-Norwegian Fisheries Case) ${ }^{4}$

Keempat, Indonesia mengirimkan delegasi untuk mengikuti Konferensi PBB I (1958) tentang Hukum Laut di Jenewa guna memperjuangkan prinsip-prinsip negara kepulauan. Dalam kesempatan tersebut Delegasi Indonesia belum berhasil karena hasil konferensi menetapkan bahwa lebar laut teritorial suatu negara pantai adalah 3 mil laut dan wilayah laut di luar laut teritorial merupakan laut lepas dimana berlaku kebebasan laut lepas. Indonesia berdasarkan KHL $1958^{5}$ memiliki laut teritorial 3 mil laut mengelilingi setiap pulau dan perairan laut di antara pulau-pulau yang berada di luar laut teritorial berstatus sebagai laut lepas. ${ }^{6}$ Dengan demikian wilayah NKRI belum merupakan satu kesatuan wilayah yang utuh.

Kelima, Deklarasi Djuanda 1957 diperkuat dengan pengundangan UU Nomor 4 Prp Tahun 1960 tentang Perairan Indonesia. ${ }^{7}$ Pada tahun yang sama (1960), Konferensi PBB II tentang Hukum Laut diselenggarakan di Jenewa dan menghasilkan KHL 1960 yang menetapkan antara lain bahwa laut teritorial tetap 3 mil laut dengan perairan laut di luarnya merupakan laut lepas. Menyadari keadaan tersebut, pemerintah Indonesia meningkatkan politik diplomasi hukum laut untuk memperjuangkan prinsip-prinsip negara kepulauan guna mewujudkan satu kesatuan wilayah NKRI.

Keenam, hasil diplomasi hukum laut Indonesia turut memberikan kontribusi positif terhadap dimulainya Konferensi PBB III tentang Hukum Laut pada akhir tahun 1973 berdasarkan General Assembly Resolution 3067 (XXVIII). ${ }^{8}$ Selama Konferensi PBB III berlangsung antara tahun 1973 sampai dengan 1982, lebar laut teritorial
Indonesia masih tetap didasarkan pada KHL 1958 yaitu 3 mil laut, perairan laut di antara pulau-pulau di luar laut teritorial masih berstatus sebagai laut lepas, ${ }^{9}$ dan satu kesatuan wilayah NKRI belum dapat terwujud.

Ketujuh, Indonesia pada tahun 1973 mengundangkan UU Nomor 1 Tahun 1973 tentang Landas Kontinen. Landas kontinen adalah wilayah dasar laut sebagai kelanjutan alamiah dari daratan yang diukur dari garis pangkal kepulauan sampai dengan batas terluar yang ditandai oleh continental rise atau continental slope. Pengundangan UU Nomor 1 Tahun 1973 tersebut didahului dengan Pengumuman Pemerintah RI tentang Landas Kontinen Indonesia pada tahun 1969. Kedelapan, Indonesia pada tahun 1980 mengundangkan UU Nomor 5 Tahun 1980 tentang Zona Ekonomi Eksklusif Indonesia. Zona Ekonomi Eksklusif Indonesia ini merupakan wilayah laut dengan lebar 200 mil laut diukur dari garis pangkal kepulauan atau 188 mil laut diukur dari batas luar laut teritorial.

Kesembilan, KHL 1982 ditandatangani oleh 119 delegasi pada tanggal 10 Desember 1982 di Montego Bay, Jamaica. ${ }^{10}$ Prinsip-prinsip negara kepulauan yang diperjuangkan oleh Delegasi Indonesia bersama-sama dengan delegasi-delegasi dari negara kepulauan lainnya diterima dan diatur dalam Bab IV KHL 1982 dengan judul Archipelagic States. Namun demikian, wilayah NKRI menurut hukum laut internasional masih belum utuh sebagai satu kesatuan karena KHL 1982 belum dapat diberlakukan, sedangkan yang diberlakukan masih tetap KHL 1960.

Kesepuluh, Indonesia pada tahun 1985 meratifikasi KHL 1982 melalui UU Nomor 17 Tahun 1985 tentang Pengesahan Konvensi PBB tentang

Ibid, hlm. 34, 35, 37, 38, 41, 56, 57, 61, 80.

Indonesia meratifikasi KHL 1958 melalui Undang-Undang Nomor 19 Tahun 1961 (Tambahan Lembaran Negara Nomor 2318) dan tidak meratifikasi KHL 1960.

Mochtar Kusumaatmadja, 1995, Masalah Lebar Laut Teritorial pada Konperensi-Konperensi Hukum Laut Jenewa (1958 dan 1960), Pusat Studi Wawasan Nusantara dan Pembangunan, Bandung.

Undang-Undang Nomor 4 Prp Tahun 1960 sudah diganti dengan Undang-Undang Nomor 6 Tahun 1996 tentang Perairan Indonesia (Tambahan Lembaran Negara Republik Indonesia Nomor 3647).

Bernado Zuleta, 1983, Introduction, United Nations Convention on the Law of the Sea, United Nations Publication, New York, hlm. xxi.

Mochtar Kusumaatmadja, Loc.cit.

United Nations, 1983, United Nations Convention on the Law of the Sea, United Nation Publication, New York, hlm. 192. 
Hukum Laut. Walaupun demikian, beberapa negara, khususnya negara-negara besar yang memiliki kekuatan maritim, belum mengakui wilayah NKRI sebagai satu kesatuan wilayah kepulauan. Kesebelas, negara ke 60 meratifikasi KHL 1982 pada tahun 1994 dan sejak saat itu berdasarkan Pasal 308 ayat (1) KHL 1982, KHL 1982 diberlakukan dan mengikat secara internasional. Sebagai konsekuensinya, wilayah NKRI berdasarkan KHL 1982 diakui secara internasional sebagai satu kesatuan wilayah kepulauan terbesar di dunia. ${ }^{11}$

\section{Diplomasi Hukum Laut Indonesia}

Sebagaimana diuraikan di atas, diplomasi hukum laut yang dilakukan oleh Indonesia dalam forum Konferensi PBB I (1958) dan Konferensi PBB II (1960) belum membuahkan hasil seperti yang diharapkan. Oleh karena itu, Indonesia melakukan diplomasi untuk menggalang solidaritas negaranegara kepulauan guna memperjuangkan prinsipprinsip negara kepulauan diterima oleh masyarakat internasional. Di samping itu, Indonesia melakukan pendekatan-pendekatan ke negara-negara tetangga yang berbatasan langsung dengan Indonesia dengan tujuan agar mereka mau mengakui Indonesia sebagai negara kepulauan. Kerjasama antar negara-negara kepulauan tersebut berlanjut dengan pelaksanaan diplomasi dalam kerangka Konferensi PBB III tentang Hukum Laut. Hasil yang diperoleh adalah pengakuan internasional terhadap prinsip-prinsip negara kepulauan yang dimuat sebagai ketentuanketentuan hukum dalam Bab IV KHL 1982 dengan judul Archipelagic States.

Sementara itu, diplomasi Indonesia terhadap Malaysia menghasilkan suatu kesepahaman bahwa Malaysiamengakuiprinsip-prinsipnegarakepulauan dengan silih (trade off) Indonesia memberikan izin kepada Malaysia untuk melakukan hubungan antara Malaysia Barat(Semenanjung Malaka) dan Malaysia Timur (Serawak) melalui wilayah laut dan udara Indonesia, serta hak perikanan tradisional kepada nelayan bubu Malaysia di perairan Pulau Anambas.
Sedangkan diplomasi Indonesia terhadap Singapura sebagai negara yang secara geografis kurang beruntung (geographically disadvantage state) membuahkan kerjasama dalam latihan militer di wilayah tertentu di Pulau Sumatera yang dituangkan dalam Defence Cooperation Arrangement (DCA), pemanfaatan wilayah laut dan udara perbatasan untuk kepentingan lalu lintas laut dan udara, dan pemanfaatan-pemanfaatan pasir laut di Kepulauan Riau untuk reklamasi daratan Singapura sebagai imbalan atas pengakuan Singapura terhadap prinsipprinsip negara kepulauan.

Di samping itu, Indonesia juga melakukan diplomasi terhadap perusahaan-perusahaan pertambangan minyak dan gas bumi dari negara-negara maritime powers dengan maksud agar perusahaanperusahaan tersebut mengakui prinsip-prinsip negara kepulauan Indonesia sebagai prasyarat diberikannya izin investasi pertambangan minyak dan gas bumi. Tujuan akhir dari diplomasi tersebut adalah bahwa negara-negara maritime powers yang telah menikmati hasil pertambangan minyak dan gas bumi dalam jangka panjang mau mengakui atau paling tidak mau mendukung upaya diplomasi hukum laut Indonesia dalam memperjuangkan agar prinsip-prinsip negara kepulauan Indonesia diakui dan diterima oleh masyarakat internasional. Dapat ditambahkan di sini bahwa perjanjianperjanjian penyelesaian batas-batas maritim antara Indonesia dan negara tetangga dapat dipandang sebagai indikator bahwa negara-negara tersebut mengakui keberadaan Indonesia sebagai negara kepulauan. Penyelesaian batas-batas maritim tersebut merupakan hasil diplomasi hukum laut yang dilakukan oleh Indonesia.

\section{Rezim Hukum Laut Indonesia}

Wilayah laut Indonesia sebagaimana diatur oleh KHL 1982 meliputi beberapa rezim hukum laut. Keberadaan rezim-rezim hukum laut sebagai bagian dari perairan Indonesia didasarkan pada garis pangkal kepulauan. Garis pangkal kepulauan

11 Amandemen kedua UUD 1945 yang disahkan pada tanggal 18 Agustus 2000 melalui Pasal 25A menetapkan bahwa "NKRI adalah sebuah negara kepulauan yang berciri Nusantara dengan wilayah yang batas-batas dan hak-haknya ditetapkan dengan Undang-Undang". 
merupakan garis-garis pangkal lurus yang menghubungkan titik-titik terluar dari pulau-pulau terluar mengelilingi kepulauan Indonesia dengan persyaratan sebagaimana diatur dalam Pasal 47 jo. Pasal 7 KHL 1982. Rezim-rezim hukum laut Indonesia meliputi. Perairan pedalaman (internal waters) adalah perairan yang berada di sisi dalam garis pangkal kepulauan mengarah ke daratan. Tegasnya, perairan pedalaman adalah perairan yang terletak antara garis pangkal kepulauan dengan daratan. Indonesia memiliki kedaulatan penuh atas perairan pedalaman dengan kewajiban untuk menjamin dapat terselenggaranya hak lintas damai di perairan tersebut (Pasal 50 jo. Pasal 8-11 KHL 1982).

Perairan nusantara (archipelagic waters) adalah perairan yang berada di antara pulaupulau dengan batas luarnya adalah garis pangkal kepulauan (Pasal 49 KHL 1982). Indonesia mempunyai kedaulatan penuh atas wilayah laut, dasar laut dan subsoil, serta udara di atasnya berikut sumber daya alam yang terkandung di dalamnya dengan kewajiban untuk menjamin terselenggaranya hak lintas damai (Pasal $52 \mathrm{KHL}$ 1982) dan hak lintas pada alur-alur laut kepulauan Indonesia (Pasal 53 KHL 1982), serta menghormati hak-hak penangkapan ikan tradisional, hak-hak yang terbit dari perjanjian-perjanjian yang telah ada dan hak-hak atas kabel dan pipa dasar laut yang telah ada (Pasal 51 KHL 1982).

Laut teritorial (territorial sea) adalah perairan selebar 12 mil laut diukur dari garis pangkal kepulauan dimana Indonesia memiliki kedaulatan penuh atas wilayah laut, dasar laut, subsoil, dan udara di atasnya berikut sumber daya alam yang terkandung di dalamnya. Indonesia mempunyai kewajiban untuk menjamin terselenggaranya hak lintas damai baik melalui alur-alur kepulauan maupun alur-alur tradisional untuk pelayaran internasional (Pasal 49, 52 dan 53 KHL 1982). Zona tambahan (contiguous zone): Pasal $48 \mathrm{KHL}$
1982 memberi peluang kepada negara kepulauan untuk mendeklarasikan zona tambahan selebar 24 mil laut diukur dari garis pangkal kepulauan atau 12 mil laut diukur dari batas luar laut teritorial, namun demikian Indonesia belum memanfaatkan peluang tersebut.

Zona ekonomi eksklusif (exclusive economic zone) adalah perairan laut selebar 200 mil laut diukur dari garis pangkal kepulauan atau 188 mil laut diukur dari batas luar laut teritorial (Pasal 55 jo. Pasal 57 KHL 1982). Indonesia mempunyai hak-hak berdaulat untuk melakukan eksplorasi, eksploitasi, konservasi, dan pengelolaan sumber daya alam, baik hayati maupun non hayati, yang terkandung di perairan, dasar laut, dan subsoil, pendirian bangunan laut, penelitian ilmiah kelautan, dan perlindungan lingkungan laut (Pasal $56 \mathrm{KHL}$ 1982). Perairan ZEE berstatus laut lepas, demikian juga status udara di atasnya. Di wilayah tersebut berlaku kebebasan bagi pelayaran dan penerbangan. Ketentuan-ketentuan hukum mengenai ZEE diatur dalam UU Nomor 5 Tahun 1980 tentang ZEE Indonesia dan Bab V KHL 1982.

Landas kontinen (continental shelf) adalah wilayah dasar laut termasuk subsoil yang merupakan kelanjutan alamiah dari daratan pulau-pulau Indonesia. Bila kelanjutan alamiah tersebut bersifat landai, maka batas terluar landas kontinen ditandai dengan adanya continental slope atau continental rise. Bila kelanjutan alamiah bersifat curam secara mendadak tidak jauh dari letak garis pangkal kepulauan, maka batas terluar landas kontinen berimpit dengan batas luar ZEE, yaitu 200 mil laut diukur dari garis pangkal kepulauan. Ketentuan hukum landas kontinen tersebut diatur dalam UU Nomor 1 Tahun 1973 tentang Landas Kontinen Indonesia dan Bab VI KHL 1982. ${ }^{12}$

\section{Perbatasan Wilayah Laut Indonesia}

Batas-batas wilayah laut Indonesia di bagian utara sebagian terbesar berbatasan dengan negara tetangga, yaitu India, Thailand, Malaysia, Singapura, 
Vietnam, Pilipina, Palau, dan Papua New Guinea, sedangkan di bagian selatan berbatasan dengan Australia dan Timor Leste. ${ }^{12}$ Batas-batas wilayah laut tersebut terdiri dari batas-batas laut teritorial, ZEE, dan landas kontinen yang akan diselesaikan melalui perundingan. Batas-batas wilayah laut yang telah diselesaikan meliputi: ${ }^{13}$

a) Batas landas kontinen antara Indonesia dan Malaysia yang disahkan melalui Keppres Nomor 89 Tahun 1989 tentang Pengesahan Hasil Perundingan Batas Landas Kontinen Bersama Indonesia dan Malaysia di Selat Malaka, dan di Laut Cina Selatan (Bagian Barat dan Timur).

b) Batas laut wilayah (laut teritorial) antara Indonesia dan Malaysia yang disahkan melalui UU Nomor 2 Tahun 1971 tentang Penetapan Hasil Perundingan Garis Batas Laut Wilayah Bersama antara Indonesia dengan Malaysia di Selat Malaka.

c) Batas landas kontinen antara Indonesia dan Australia yang disahkan melalui Keppres Nomor 42 Tahun 1971 tentang Pengesahan Hasil Perundingan Batas Dasar Laut Tertentu antara Indonesia dengan Australia di Laut Arafura dan di Sebelah Selatan Pulau Irian, dan Keppres Nomor 20 Tahun 1972 tentang tentang Pengesahan Hasil Perundingan Garis-Garis Batas Landas Kontinen Bersama antara Indonesia dengan Australia di Laut Timor dan Laut Arafura.

d) Batas laut teritorial antara Indonesia dan Papua New Guinea di utara dan selatan Pulau Irian yang disahkan bersama dengan batas-batas darat melalui UU Nomor 6 Tahun 1973 tentang Pengesahan Hasil Perundingan Garis-Garis Batas Tertentu antara Indonesia dan Papua New Guinea.

e) Batas laut teritorial antara Indonesia dan Singapura yang disahkan melalui UU Nomor 7 Tahun 1973 tentang
Pengesahan Hasil Perundingan Garis-Garis Batas Tertentu antara Indonesia dengan Singapura di Selat Singapura (Bagian Tengah). Garis batas di bagian barat Selat Singapura telah diselesaikan melalui dua kali perundingan, yaitu pada tahun 2009 dan 2010, sedangkan garis batas di bagian timur Selat Singapura sampai saat ini belum terselesaikan.

f) Batas laut teritorial antara Indonesia dan India (Kepulauan Andaman) yang disahkan melalui Keppres Nomor 51 Tahun 1974 tentang Pengesahan Hasil Perundingan Garis-Garis Batas Tertentu antara Indonesia dengan India di Laut Andaman.

g) Batas landas kontinen antara Indonesia dan India yang disahkan melalui Keppres Nomor 26 Tahun 1977 tentang Pengesahan Hasil Perundingan Garis Batas Landas Kontinen Bersama antara Indonesia dengan India di Laut Andaman dan Samudera Hindia.

Uraian di atas memberi gambaran bahwa belum seluruh batas wilayah laut antara Indonesia dan negara tetangga terselesaikan. Dengan demikian batas luar wilayah laut Indonesia belum utuh sepenuhnya. Beberapa prinsip penyelesaian batas wilayah laut yang senantiasa perlu diperhatikan dan dipertimbangkan oleh Indonesia adalah sebagai berikut:

a) Prinsip garis tengah (median line principle), yaitu prinsip penyelesaian garis batas wilayah laut antar negara yang letak geografisnya saling berhadapan. Misalnya, penyelesaian garis batas laut wilayah antara Indonesia dan Malaysia di Selat Malaka pada tahun 1971.

b) Prinsip sama jarak (equidistance principle), yaitu prinsip penyelesaian garis batas wilayah laut antar negara yang letak geografisnya saling berdampingan. Misalnya, penyelesaian garis batas laut wilayah di utara

12 Indonesia memiliki 12 (dua belas) pulau terluar prioritas yang merupakan bagian dari 92 (sembilan puluh dua) pulau terluar yang berbatasan dengan negara tetangga. Ke-92 pulau terluar tersebut merupakan lokasi dari titik-titik terluar yang dihubungkan dengan garis pangkal lurus menjadi garis pangkal kepulauan (Peraturan Pemerintah Nomor 38 Tahun 2002 tentang Daftar Koordinat Geografis Titik-Titik Garis Pangkal Kepulauan Indonesia). Lihat Achmad Jusnadi, Herie Saksono dan Suryo Sakti, 2005, Platform Penanganan Permasalahan Perbatasan Antarnegara, Direktorat Wilayah Administrasi dan Perbatasan, Direktorat Jendral Pemerintahan Umum, Departemen Dalam Negeri, Jakarta, hlm. 33-36.

13 Ibid., hlm. 76-77. 
dan di selatan Pulau Irian (Papua) sebagai kelanjutan garis-garis batas di darat antara Indonesia dan Papua New Guinea. Penyelesaian tersebut disahkan dengan UU Nomor 6 Tahun 1973.

c) Prinsip keadilan (equitable principle), yaitu prinsip penyelesaian batas wilayah laut didasarkan pada keadilan dan bukan didasarkan pada kondisikondisi fisik alamiah semata. Prinsip keadilan tersebut dijadikan landasan karenadalamperundinganpenyelesaian batas wilayah tersebut dipertaruhkan kepentingan-kepentingan ekonomi, sosial, dan budaya dari salah satu negara yang menjadi pihak dalam perundingan. Misalnya, Filipina memakai prinsip keadilan dalam perundingan penyelesaian batas ZEE di Laut Sulawesi dengan Indonesia yang mempergunakan prinsip garis tengah. Posisi kedua negara tersebut telah menjadi tumpuan bagi Filipina untuk memperjuangkan agar perairan ZEE yang dibahas dalam meja perundingan adalah wilayah laut yang dibatasi oleh garis tengah yang diusulkan oleh Indonesia dan garis batas penangkapan ikan nelayannelayan Filipina yang diklaim oleh Pilipina sampai ZEE Indonesia. Dalam kaitan ini, Pilipina memperjuangkan kepentingan perikanan dari para nelayannya yang telah lama berada di wilayah laut Indonesia. Perbedaan prinsip tersebut telah mengakibatkan terhentinya perundingan penyelesaian garis batas ZEE di Laut Sulawesi antara Indonesia dan Pilipina.

d) Prinsip kelanjutan alamiah (natural prolongation principle), yaitu prinsip penyelesaian batas landas kontinen yang didasarkan pada kelanjutan ciri-ciri alamiah dari daratan sampai ke dasar laut. Misalnya, Vietnam mempergunakan keberadaan thalweg (sungai di dasar laut sebelum zaman es mencair) dan sedimentasi lumpur Sungai Mekong yang mempunyai kelanjutan alamiah sampai ke Pulau Natuna untuk sebagai prinsip penyelesaian batas landas kontinen dengan Indonesia di Laut Cina Selatan bagian selatan. Vietnam berdasarkan prinsip tersebut mengklaim bahwa wilayah landas kontinen yang harus dirundingkan adalah wilayah dasar laut yang terletak antara garis tengah (median line) yang diusulkan oleh Indonesia dan kelanjutan alamiah thalweg dan lumpur Sungai Mekong yang mencapai dasar laut Pulau Natuna. Jadi wilayah landas kontinen yang diklaim oleh Vietnam untuk dirundingkan sebenarnya adalah wilayah landas kontinen yang diklaim oleh Indonesia berdasarkan median line principle.

Garis-garis batas wilayah laut antara Indonesia dan negara tetangga yang belum ditetapkan perlu segera diselesaikan melalui perundinganperundingan agar kedaulatan dan hak-hak berdaulat Indonesia dapat benar-benar ditegakkan di wilayah laut yang menjadi yurisdiksi Indonesia.

\section{Wilayah Laut Pusat dan Daerah}

UU Nomor 4 Tahun 1975 tentang PokokPokok Pemerintahan di Daerah belum mengatur kewenangan pemerintah daerah atas wilayah laut. Hal ini disebabkan oleh karena pada saat dimulainya diplomasi hukum laut, pemerintah belum memikirkan tentang pentingnya pemberian kewenangan atas suatu wilayah laut tertentu kepada pemerintah daerah. Ketika pemerintah menyadari bahwa kemampuannya untuk mengurus wilayah laut di sepanjang $81.900 \mathrm{~km}$ garis pantai terbatas, maka pemerintah mulai memberikan kewenangan atas suatu wilayah laut tertentu kepada pemerintah daerah melalui UU Nomor 22 Tahun 1999 tentang Pemerintah Daerah yang kemudian diganti dengan UU Nomor 32 Tahun 2004 tentang Pemerintah Daerah. Pergantian Undang-Undang tersebut tidak mengubah ketentuan hukum yang mengatur kewenangan pemerintah daerah atas suatu wilayah laut tertentu.

Pemerintah provinsi memiliki kewenangan atas wilayah laut selebar 12 mil laut diukur dari garis pantai dan pemerintah kabupaten atau pemerintah kota memiliki kewenangan atas wilayah laut selebar sepertiga dari wilayah laut yang menjadi 
kewenangan pemerintah provinsi. Garis pantai dalam kaitan ini merupakan garis pangkal lurus yang menghubungkan titik-titik terluar dari pantai suatu daerah dengan ketentuan bahwa jarak antara dua titik yang dihubungkan tersebut tidak boleh lebih dari 12 mil laut. Pemerintah daerah berwenang melakukan kegiatan eksplorasi, eksploitasi, pengelolaan, dan konservasi di wilayah laut yang menjadi kewenangannya. Kewenangan pemerintah daerah tersebut perlu dipetakan pada peta wilayah laut daerah yang dilampirkan pada suatu peraturan pelaksanaan UU Nomor 32 Tahun 2004 tentang Pemerintah Daerah. Upaya untuk mengatur pelaksanaan kewenangan pemerintah daerah atas wilayah laut daerah sampai saat ini belum dapat terlaksana sebagaimana diharapkan. Sambil menunggu terlaksananya kewenangan pemerintah daerah atas wilayah laut daerah, pemerintah diharapkan segera mengantisipasi keadaan tersebut dengan memberi tugas pembantuan kepada pemerintah daerah untuk melaksanakan urusan pemerintah di wilayah laut daerah yang menjadi bagian dari wilayah laut Indonesia yang berbatasan langsung dengan negara tetangga.

\section{Kebijakan Kelautan Nasional tentang Wilayah Laut Indonesia}

Kebijakan kelautan nasional atau national ocean policy secara umum dapat dipahami sebagai arah dari berbagai macam kegiatan pembangunan kelautan nasional yang diselenggarakan di wilayah laut Indonesia untuk mewujudkan, melindungi, dan mempertahankan kepentingan-kepentingan nasional, termasuk kepentingan kelautan setiap warga negara. Wilayah laut Indonesia merupakan bagian penting dari keseluruhan pembangunan kelautan nasional. Kapasitas potensial (potential capacity) yang terkandung di dalam wilayah laut Indonesia perlu diberdayakan menjadi daya dukung (carrying capacity) dan daya tampung (absorptive capacity) yang memadai untuk mendukung dan menampung kegiatan-kegiatan pembangunan kelautan nasional.

Sehubungan dengan maksud tersebut di atas, kebijakan kelautan nasional haruslah memiliki komponen kebijakan tentang wilayah laut Indonesia. Kebijakan kelautan nasional tentang wilayah laut Indonesia terdiri dari kebijakan umum, kebijakan teknis, dan kebijakan pelaksanaan. Kebijakan umum hendaknya berisi arahan-arahan tentang cara pandang negara dan warga negara dalam memaknai wilayah laut sebagai masa depan bangsa. Cara pandang seperti ini disebut Wawasan Nusantara. Wilayah laut sebagai masa depan bangsa menjadi tidak bermakna apa bila tidak diisi dengan pembangunan kelautan nasional dan pelaksanaan pembangunan kelautan nasional merupakan implementasi Wawasan Nusantara. Landasan dari implementasi Wawasan Nusantara adalah kedaulatan dan hak-hak berdaulat Indonesia di wilayah laut.

Untuk menjadikan wilayah laut Indonesia bermakna bagi masa depan bangsa melalui implementasi Wawasan Nusantara, maka pemerintah perlu merumuskan kebijakan teknis yang berisi arahan-arahan tentang bagaimana caranya menegakkan kedaulatan dan hak-hak berdaulat dari negara dalam rangka eksplorasi, eksploitasi, pengelolaan, dan konservasi wilayah laut Indonesia beserta seluruh kekayaan alam yang terkandung di dalamnya sesuai KHL 1982 serta ketentuan-ketentuan hukum terkait lainnya yang berlaku.

Dalam kaitan dengan uraian di atas, kebijakan pelaksanaan yang dirumuskan pemerintah hendaknya berisi arahan-arahan tentang bagaimana caranya agar supaya kedaulatan dan hak-hak berdaulat Indonesia dapat ditegakkan di wilayah laut Indonesia. Dalam kaitan ini diketahui bahwa batas-batas wilayah laut Indonesia, baik yang berhadapan atau berdampingan maupun yang tidak berhadapan atau tidak berdampingan dengan negara tetangga, belum seluruhnya terselesaikan. Oleh karena itu, langkah-langkah yang perlu dilakukan agar implementasi Wawasan Nusantara dapat terlaksana antara lain adalah melanjutkan diplomasi perundingan penyelesaian garis-garis batas wilayah laut dengan negara tetangga, menetapkan batas luar wilayah laut Indonesia yang tidak berhadapan 
atau tidak berdampingan dengan negara tetangga, memetakan batas-batas wilayah laut tersebut dan mendepositkannya ke PBB, serta melanjutkan dan meningkatkan pembangunan kelautan nasional.

\section{Penutup}

Tinjauan hukum laut terhadap wilayah NKRI sebagaimana diuraikan di atas telah memberi pengertian, pemahaman, dan pengetahuan bahwa sejak KHL 1982 diberlakukan dan mengikat secara internasional pada tahun 1994 wilayah laut Indonesia merupakan bagian yang tak terpisahkan dari wilayah NKRI. Wilayah laut Indonesia tidak lagi menjadi pemisah pulau-pulau melainkan menjadi perekat yang mempersatukan pulau-pulau dengan perairan laut dan udara di atasnya sebagai satu kesatuan tanah air

Diberlakukannya KHL 1982 dan mengikat secara internasional pada tahun 1994 telah memberi pengertian, pemahaman, dan pengertian bahwa wilayah NKRI baru benar-benar menjadi satu kesatuan wilayah negara pada tahun 1994, bukan sejak diproklamasikan pada 17 Agustus 1945. Hampir selama 50 tahun NKRI diselenggarakan tanpa keutuhan wilayah. Walaupun keutuhan wilayah tersebut saat ini sudah terpenuhi berdasarkan KHL 1982, namun kenyataan menunjukkan bahwa batas-batas luar wilayah laut Indonesia masih banyak yang belum terselesaikan. Kenyataan ini memberi gambaran bahwa diplomasi hukum laut perlu dilanjutkan dan ditingkatkan.

Untuk mempertahankan dan memperkuat status hukum wilayah laut Indonesia sebagai bagian yang tak terpisahkan dari wilayah NKRI, maka pemerintahan negara perlu hadir secara nyata melalui pengimplementasian Wawasan Nusantara yang antara lain dapat berupa penegakan kedaulatan dan hak-hak berdaulat di laut serta pelaksanaan pembangunan kelautan nasional yang melibatkan pemerintah daerah dan seluruh warga negara.

\section{DAFTAR PUSTAKA}

\section{A. Buku}

Churchill, R.R. and A.V. Lowe, 1999, The Law of the Sea, Manchester University Press, Manchester.

Jusnadi, Achmad, Herie Saksono dan Suryo Sakti, 2005, Platform Penanganan Permasalahan Perbatasan Antarnegara, Direktorat Wilayah Administrasi Perbatasan, Direktorat Jenderal Pemerintahan Umum, Departemen Dalam Negeri, Jakarta.

Kusumaatmadja, Mochtar, 1995, Masalah Lebar Laut Teritorial Pada Konperensi-Konperensi Hukum Laut Jenewa (1958 dan 1960), Pusat Studi Wawasan Nusantara, Hukum dan Pembangunan, Bandung.

Kusumaatmadja, Mochtar, 1995, Hukum Laut Internasional, Pusat Studi Wawasan Nusantara, Hukum dan Pembangunan, Bandung.

Prescott, J.R.V., 1985, The Maritime Political
Boundaries of the World, Methuen, London.

Siombo, Marhaeni Ria, 2010, Hukum Perikanan Nasional dan Internasional, Gramedia Pustaka Utama, Jakarta.

Sumardiman, Adi, et al., 1982, Wawasan Nusantara, Surya Indah, Jakarta.

Sumardiman, Adi, 1992, Wilayah Indonesia dan Dasar Hukumnya, Pradnya Paramita, Jakarta. United Nations, 1983, United Nations Convention on the Law of the Sea, United Nations Publication, New York.

Wibowo, Antonius P.S., 2000, Menyambut Sistem Kelautan Indonesia Baru, Atma Jaya, Jakarta.

\section{B. Artikel Jurnal}

Purwaka, Tommy Hendra, "Paradigm Shift in the Implementation of the Law of the Sea in Indonesia", Indonesian Journal of International Law, Vol. 8, No. 1, Oktober 2010 


\section{Peraturan Perundang-Undang}

Undang-Undang Dasar Negara Republik Indonesia Tahun 1945.

Undang-Undang Nomor 4 Prp Tahun 1960 tentang Perairan Indonesia (Tambahan Lembaran Negara Republik Indonesia Nomor 1942).

Undang-Undang Nomor 19 Tahun 1961 tentang Ratifikasi atas Tiga Konvensi Jenewa Tahun 1958 (Tambahan Lembaran Negara Republik Indonesia Nomor 2318).

Undang-Undang Nomor 2 Tahun 1971 tentang Pengesahan Hasil Perundingan Garis Batas Laut Wilayah Bersama antara Indonesia dengan Malaysia di Selat Malaka (Lembaran Negara Republik Indonesia Tahun 1971 Nomor 16).

Undang-Undang Nomor 1 Tahun 1973 tentang Landas Kontinen Indonesia (Tambahan Lembaran Negara Republik Indonesia Nomor 2994).

Undang-Undang Nomor 6 Tahun 1973 tentang Pengesahan Hasil Perundingan Garis-Garis Batas Tertentu antara Indonesia dengan Papua New Guinea (Tambahan Lembaran Negara Republik Indonesia Nomor 3017).

Undang-Undang Nomor 7 Tahun 1973 tentang
Pengesahan Hasil Perundingan Garis-Garis Batas Tertentu antara Indonesia dengan Singapura di Selat Singapura (Lembaran Negara Republik Indonesia Tahun 1973).

Undang-Undang Nomor 4 Tahun 1975 tentang Pokok-Pokok Pemerintahan di Daerah (Tambahan Lembaran Negara Republik Indonesia Nomor 3063).

Undang-Undang Nomor 5 Tahun 1983 tentang Zona Ekonomi Eksklusif Indonesia (Tambahan Lembaran Negara Republik Indonesia Nomor 3260).

Undang-Undang Nomor 17 Tahun 1985 tentang Ratifikasi Konvensi PBB 1982 tentang Hukum Laut (Lembaran Negara Republik Indonesia Nomor 76 Tahun 1985).

Undang-Undang Nomor 6 Tahun 1996 tentang Perairan Indonesia (Tambahan Lembaran Negara Republik Indonesia Nomor 3674).

Undang-Undang Nomor 22 Tahun 1999 tentang Pemerintah Daerah (Lembaran Negara Republik Indonesia Nomor 60 Tahun 1999). Undang-Undang Nomor 32 Tahun 2004 tentang Pemerintah Daerah (Tambahan Lembaran Negara Republik Indonesia Nomor 3563). 